\title{
Kaliningrad
}

\section{ANDREAS ROEPSTORFF}

EU varmer i ganen, forbereder $\mathrm{RO}$, der spytter ud over tandkanten, mens PA synker tilbage mod halsens trykke mørke og smagen af ordet trækker et velkendt kort med sig. Det kommer rullende ind fra højre, og jeg genkender konturerne af vand til venstre, så land, øer bjerge, og jeg finder mig selv stående i fyrtårnet lidt mod nord. Og ordet ruller igen ind fra højre, og kortet duver lidt om sin guldbelagte akse gennem Greenwich, og jeg ser i retningen det kommer fra, og ser ingenting, og ser derfor mod syd hvor den velkendte støvle former sig for mine øjne, og jeg følger lyden rundt med solen, og den trækker ud over havet, til den fortoner sig i vest. Og ordet ruller ind igen, men denne gang kastes et svagt ekko tilbage fra havet som rammer det næste ord der kommer bølgende. Mens ordet opløses i lyd sender det små rystelser gennem kortet, og det giver sig om utallige akser, og det velkendte billede opløses, og i stedet stabiliserer det sig momentant i et konkret sted og en konkret tid. Og det er Budapest, juli 1988. I hundredetusindvis vandrer vi forbi den rumænske ambassade i protest mod diktatoren i nabolandet, og der hviskes om nationens transylvanske helte. Og i sidegaderne står vandkanonerne på stribe, mens de højtråbende angste tysses ned. Og ordet ruller igen. Og jeg er i Sibiu, i selvsamme naboland. Og over den hjemmelavede snaps siger tyskeren til mig: "vi sætter kulturen, højt, derfor har vi købt video og fjernsyn, så vi kan se programmer fra den anden side, de cirkulerer rundt blandt os, smuglet ind". Og det er juli 1989. Og fem måneder senere er diktatoren død, og jeg står i Berlin, og det er den 31. december, og det er den største nytårsfest i Europa, og alle italienerene er her, og de udfordrende kvinder springer op på muren, og de østtyske soldater 
ved ikke om de skal skyde eller lade sig fotografere med dem. Og kort tid efter er der ikke længere nogen mur, og Europa har ingen grænse mod øst, og ordet kommer stadig rullende, længere og længere østfra, og kortet er gået i selvsving, og jeg kan intet genkende uden for fyrtårnet.

Og det stabiliserer sig igen i et punkt og det er 1. maj i Kaliningrad og året er 1995 og for 50 år siden sluttede krigen. Foran den kraftfuldt fremadskridende Leninskulptur på sejrspladsen, Plosjad Pobeda, opløser en lille demonstration med røde faner sig selv og kun nogle få tulipaner viser, at den gamle mand stadig bliver respekteret hist og her. I parken bag ham markerer en noget større menneskemængde, et nyt trækors og endnu flere blomster at her starter snarest byggeriet af en katedral for den ortodokse kirke. Men Lenin, der nu afløses af kirken, er ikke den første ændring, der påføres byen i det sydøstligste hjørne af Østersøen. Tidens gang afsløres $\mathrm{i}$ historiens indskrivninger $\mathrm{i}$ byens rum, dens stene og dens stednavne. Plosjad Pobeda, hvor for nylig kommunistpartiets og KGBs hovedkvarter lå, hed indtil 1945 Adolf Hitler Platz, og husede Gestapo og Nazipartiet og før det, Hansa Platz. Mens den nærvedliggende Jurij Gagarin gade hed Hermann Göring Strasse og før det, Königs Strasse. Og sådan har alle steder i denne by også et navn, der viser tilbage til dengang byen var kendt som Königsberg, det kulturelle centrum i Østpreussen. Gennem århundrede kendt i Europa som et af den tyske kulturs højborge. Her kunne man i 1700 tallets sidste forvirrede halvdel stille sit ur efter Immanuel Kants daglige spadseretur. Her spekulerede han over tiden og rummet: „Ved hjælp af den ydre sans (en egenskab ved vort gemyt) forestiller vi os genstandene som værende uden for os. I dette er deres facon, størrelse, og indbyrdes relation bestemt eller bestemmeligt. Den indre sans ved hvis hjælp gemyttet anskuer sig selv eller sin indre tilstand, give os ganske vist ingen anskuelse af sjælen som et objekt; men anskuelsen af den indre tilstand er kun mulig under en bestemt form: Alt som hører under det indre forestilles i tidsrelationer. Tiden kan ikke anskues som noget ydre, så lidt som rummet kan anskues som noget indre". 
Og tiden er 1. maj, og rummet er stabilt for mit blik, som et spinkelt fikspunkt i Europa. Det er ikke det geografiske centrum, det ligger nogle hundrede kilometer længere mod nordøst. Det er ikke det økonomiske centrum, det ligger adskillige hundrede kilometer mod sydvest. Og alligevel er det en periferi der står stille i orkanens øje. Springvandet foran Plochad Pobeda er netop blevet tændt i et blomsterflor, og bag det spiller et hornorkester en russisk schlager, "the lady", i et frodigt, blidt og fast swing. "Vi skal holde fast i 1. maj festen", siger vores vært, professoren. "Det er en fest for børnene, for foråret, for livet der starter på ny". Han er som alle indbyggere i Kaliningrad kommet hertil efter 2. Verdenskrig, og som mangeandre har han brugt denne Ruslands eneste isfrie havn mod vest som udgangspunkt til at arbejde og rejse på oceanerne. Her har han kortlagt Atlanterhavets havbundsformationer til brug for den sovjetiske flåde og deltaget $\mathrm{i}$ videnskabelige ekspeditioner til Sydhavsøerne. Professoren er geograf, ukrainer af nationalitet, russisk statsborger, bosat i over 25 år i denne gamle tyske by hvor hans børn og børnebørn er vokset op, og har alderen og erfaringen til at reflektere over historien. „Byen er blevet taget med vold, det er klart. Vi tog den fra tyskerne, og de blev flyttet ud, men det var krig, og de fleste af dem, der bor i byen i dag, er født her eller har boet her i 10, 20, 30 år. Hvis byen skulle gå tilbage til Tyskland skulle Amerika også give landet tilbage til indianerne, og tyskerne selv give Preussen tilbage til de gamle prøjsere".

Og byens voldelige fortid klæber sig fast til dens navne. Det sidste fra 1946 kan den takke Michail Kalinin for, der havde været Sovjetunionens officielle statsoverhoved gennem hele 2. Verdenskrig. Det var en symbolsk markering af at byen sammen med cirka en tredjedel af det tidligere Østpreussen var en del af Sovjetunionens dyrt tilkæmpede krigsbytte. Men også Königsberg refererer tilbage til en blodig erobring. Den mægtige Kong Ottokar den Anden af Böhmen deltog i vinteren 1255 i et af den tyske ordens korstog mod de hedenske prøjsere. Til ære for ham kaldte man den nyanlagte korsridderborg på den prøjsiske borghøj Tvangstò nær floden Pregels udmunding for Königsberg. De hellige korstog mod prøjserne var blevet startet næsten tredive år 
før og det varede godf tredive år yderligere inden ridderorden havde fået bemægtiget sig hele Prøjsen. De oprindelige, hedenske prøjsere, der talte det måske mest arkaiske sprog i Europa, af senere romantikere sammenlignet med sanskrit, blev i løbet af de næste fire-fem hundrede år assimileret ind i et tysk sprogrum. Kun deres navn skulle leve videre, ironisk identificeret med indbegrebet af alt hvad der er protestantisk og tysk.

Omkring slotsborgen ved bredden af Pregel og den monumentale domkirke på en $\varnothing \mathrm{i}$ floden voksede byen sig gennem en broget historie som den østligste "tyske" pol i spændingsfeltet mellem de forskellige centrer i det sydøstlige Europa, først Vilnius og Krakow, senere Stockholm, Warszawa, Sct. Petersborg og Berlin. En tid var det en selvstændig religiøs ordensstat, efter reformationen blev det et hertugdømme der først var underlagt de polske konger og senere via giftemål allieret med kurfyrstendømmet Brandenburg mod vest. Efter Polens første deling i 1772 blev Østpreussen og Brandenburg geografisk forbundet, og udfra dette kongerige Preussen med centrum i Berlin blev det moderne Tyskland samlet som geografisk og politisk enhed i 1871. Det startede på sin vis altsammen her i Königsberg i 1861. Da begyndte Wilhelm I sin royale løbebane ved at blive kronet til konge af Preussen. Få år efter var han kejser af det samlede tyske rige, og resten er en velkendt historie. Da Polen blev genoprettet som selvstændig stat efter 1 . Verdenskrig, blev Østpreussen yed Danzig-korridoren igen adskilt fra Berlin. Den blev overskredet 1. september 1939 af Die Wehrmacths soldater i fuld overensstemmelse med Molotov/Ribbentrop pagten mellem Moskva og Berlin. Da resultatet af denne Drang nach Osten blev gjort op, havde Tyskland mistet alle landområder øst for Oder-Neisse inklusiv det historiske Østpreussen, som blev delt mellem Polen og den russiske socialistiske sovjet republik.

Königsbergs historiske middelaldercentrum, udspændt mellem domkirken og slottet, blev først ødelagt i august 1944, da engelske flyvere terrorbombede det, og yderligere sønderskudt da den sovjetiske hær i april 1945 kæmpede sig vej ind i „fæstningen Königsberg". De sovjetiske sejrherrer følte forståeligt nok ikke det store behov for at restaurere ruinerne. Tværtimod, en 
anekdote fortæller at de lokale kommunistspidser konkurrerede om hvem der kunne levere flest sten til Stalingrads genopbygning. Tilbage på øen i Pregel, der engang havde 23 snævre, tæt bebyggede gader, står idag ruinerne af domkirken midt i en åben park med lidt for entydige skulpturer. Ved den ene bred ligger et lyseblåt sukkerkagepalads i italiensk renæssancestil. Tidligere var det Königsbergs børs, nu huser det sømændenes kulturhus lidt endnu. Men festsalen er allerede blevet indtaget af en stor Legoudstilling. Ellers er det geografiske centrum et funktionelt tomrum gennemskåret af brede veje og flankeret af høje beboelsesejendomme, et hotel og et sportskompleks. Og måske er dette punkt Europas decentrerede midte. Midt i det hele, på fundamentet af Königsberg slottet, ligger "Sovjeternes Hus" en gigantisk funktionalistisk H-formet skyskraber. Ruinerne af slottet blev sprængt i luften i 1969 og for at give plads til byggeriet af Kaliningrads nye administrative magtbase. I det ydre blev huset bygget færdigt, men mens man var igang med at indrette det indre skred fundamentet som i en dobbelt ironisk kommentar til sovjetsystemets legitimitet og evne til at gennemføre sine store projekter. Så kolossen sank lidt ned i mosen under vægten af de alt for mange tons beton og blev aldrig færdiggjort.

En betjent viser mig rundt. Nogle steder er de indvendige søjler blevet dækket med marmor, i en biografsal er stolene sat ind og på visse etager er parketgulvene blevet lagt, men de rå betongulve og ufærdige trapper dominerer indtrykket. Gennem knuste ruder kan man se ud over de stort anlagte fontæner, der ikke er blevet færdige eller måske blot allerede er forfaldet, over på ruinerne af domkirken. To forfaldne tanker om det bærende i civilisationen forankret i sten. „Det ligner noget en krig har kæmpet sig igennem" siger betjenten. "Vi er først begyndt at bevogte det for nyligt. Der var nogle amerikanere for at se på det, de ville lave det om til et indkøbscenter, men, men, men, der skal gøres meget, og fundamentet...". Måske er amerikanerne for sent ude. Tomrummet for foden af sovjeternes hus er allerede blevet bebygget med små røde og hvide blikbarakker der sælger italiensk mode og franske dufte. Her promenerer byens nyrige med stive 
blikke der afslører den mangel på stil, som gør BMWen og de dyre klude til udtryk for vulgaritet i stedet for elegance.

Fra korsridderborg og kongeslot over modernistisk ufuldendt magtcentrum til nyfin markedsplads, sådan skriver tiden sig fortsat ind på byens rum, hvor de symbolske pladser ikke kan blive stående som tomrum, men må skifte funktion og betydning med de nye vinde der blæser. Men historien bliver hængende som fortællinger i byens indbyggere, der ikke kan undgå at hæfte sig ved de sten og strukturer som viser tilbage til noget andet. Centralt står det futuristiske verdensur, der engang kunne vise klokken i alle afkroge af det sovjetiske imperium. Nu står de mange visere stille under byens motto "Kaliningrad - krigs- og arbejdsbyen til ære for det sovjetiske folk". Her bliver jeg indfanget af byens engel på oplysningsmission. Den har skikkelse af en ældre spinkel herre som trækker mig gennem byen, fortællende om længst forsvundne steder og stemninger. Han er russer og pensioneret fysiklærer. Var krigsfange i Königsberg fra 41 til 45 og vendte tilbage efter krigen for at arbejde i den by han ikke kan slippe. „Min far sagde til mig: du skal kende to historier dit steds historie og din families historie, alt det andet er politiske løgne og propaganda. Her lå der tre kirker, og der et gymnasium. Her var Strasse der SA. Denne bygning er meget vigtig for tysk historie. Her blev i $1820^{\prime}$ erne de preussiske landreformer vedtaget, der kom til at danne skole for hele Tyskland. Fotografér det. Det er vigtigt!“. Huset rummer i dag Østersøflådens kartografiske institut, og englen taler med den løjtnant der bevogter stedet. ",Ved De hvad, der skete her, før I kom? Dette sted er et vigtigt sted, jeg ved ikke, hvordan De har det, men jeg mener, man skal kende to historier, sit steds og sin families!". Løjtnanten, der på forhånd har tabt den kamp om historien man ikke kan sno sig ud af, må resignere og vise mig rundt. På trappeafsatsen brænder en lille elektrisk flamme midt $i$ en rød stjerne foran et billede af landgangstropper, der stormer en forreven kyst. En mindeplade med navnene på de kartografer der faldt, giver krigen som mulighed et dagligt nærvær på det sted hvor kortene, der hjalp sovjetiske Ubåde til den svenske skærgård, er blevet udarbejdet. Englen fører os videre gennem byen, forbi krigsmonumentet, 
hvor en torpedobåd med strittende torpedoer springer ud af sin betonbase i en vinkel på $30^{\circ} \mathrm{i}$ en æstetisk samling af krigen, kønnet og kunsten. Ned til domkirken, de århundrede gamle gravstene indfældet $\mathrm{i}$ kirkemuren og Kants gravsted. Jeg forsøger at få bekræftet historien om stenene, der triumferende blev brugt til at genopbygge Stalingrad, men det indignerer ham. „Det er ondsindet løgn og propaganda, der var masser af sten omkring Stalingrad, så det var ikke nødvendigt at transportere byggematerialer tværs over Sovjetunionen. Nej stenene fra Königsberg blev brugt til at genopbygge Tallin, Riga og Minsk..."

Mens jeg grunder over hvad der er vigtigst, at stenene blev sendt væk eller om de blev brugt i Stalingrad er han pludseligt forsvundet. Og jeg vandrer videre gennem byen i undren mellem regulære boligblokke malet i ubestemmelige pastelfarver, babyblå, skidengrøn, gulrosa. Er man født her før krigen, må det være forfærdeligt at komme tilbage, men jeg har ikke billedet af små snævre gader i hjertet og nyder solen, de store grønne områder, ungerne der leger, og stemningen, der har en anden drejning på trods af at arkitekturen og forfaldet, er det samme som alle andre steder i ex-Sovjet. I en stor lejlighed fra sidste århundrede, hvor brevsprækken stadig har et markant "Briefe” under de mange lag maling, drikker jeg te med to fysikere og deres to børn. Der er højt til loftet, grønne planter overalt. Hun er født i byen, hvor hendes far var chefmeteorolog på de togter, der hver sommer bragte nybyggede krigsskibe nord om Sibirien til Vladivostok ved Stillehavet. Han er opvokset i en industriby øst for Ural. Da de var færdige med universitetet kunne de vælge mellem at tage arbejde i Sevastopol på Krim eller her i byen. „Det var heldigt vi valgte Kaliningrad ellers havde vi idag siddet i Ukraine, og se hvordan det er gået", forklarer han. „Mange steder er russerne upopulære. I Kaliningrad, derimod, er der ingen problemer. Hertil kom alle slags mennesker efter krigen, russere, armenere, ukrainere, jøder, og alle blandede sig med hinanden. Som i USA var det en kulturel smeltedigel". De vil gerne have hans forældre hertil. For dér, øst for Ural, er der også folk der mener, at jorden er deres og russerne skal ud. Og russerne selv er blevet fanget ind i Sovjetunionens logik hvor mange områder havde status som 
selvstyrende region eller republik for det ene eller andet lille folk. Dengang betød navnet i sig selv ingenting, det hele blev alligevel styret fra Moskva. Men idag betyder navnene alt, for burjaterne vil styre i Burjatien, baskirerne i Baskirien og tatarerne i Tatarstan. „Identiteten har aldrig været et problem for os russerne, vi var der bare, men alle de andre dyrker deres egen identitet, så vi må også gøre noget. Vores datter er begyndt at lære traditionelt russisk kunsthåndværk i skolen. Hun laver dukker i Pșkovstil, lakskeer i Smolenskstil og påskeæg i Moskvastil og det er godt".

Det er klart, at russernes tabte overlegenhed tvinger dem til som alle andre at forsøge at definere sig selv; men handler identitet om at lære børnene traditionelt kunsthåndværk? Hvor skal man ellers lede, $\mathbf{i}$ zartidens storhed eller kommunismens hårdhændede modernisering? Og hvad med Kaliningrad idag? Selvom russerne udgør omkring $75 \%$ af områdets befolkning på knapt en million, og selvom der er under 10.000 tyskere i følge de officielle statistikker lurer bevidstheden om tyskerne lige under overfladen. De kommer rejsende hertil for at gense deres barndomshjem, og de giver penge til genopbygningen af domkirken og fodring af dyrene i zoologisk have. For nogle år siden var der uofficielle forlydender om, at de etniske tyskere fra Sovjetunionen skulle have et nyt hjemland i Kaliningradområdet; men det blev hurtigt dysset ned igen. Der var alt for mange, der ikke var interesserede $i$ at rykke ved grænserne i dette spændte område. I et rodet hjørne i udkanten af centrum ligger det tysk-russiske kulturhus bag et meterhøjt ståltrådshegn omgivet af en ordentlig, slået græsplæne. Et nybygget, lavt, murstenshus med bibliotek og foredragssal. Her siger man, at det ikke er officiel tysk politik at bosætte tyskere i området. Man vil forsøge i fællesskab med russerne at genopbygge byen og arrangere kulturelle aktiviteter for russere og tyskere, ikke mere. De grupper, der forsøger at etablere landbrugskollektiver med tyskere fra Kasakhstan og Sibirien, får ingen officiel støtte. Men de har en vis tilknytning til højrekræfter i Tyskland, der mener, at engang tysk - altid tysk. Det er en klog politik af et Tyskland, der har taget ved lære af krigen. For selvom man først bliver fanget ind i logikken $i$, at tyskere selvfølgelig skal bosættes på gammelt tysk land, holder argu- 
mentet ikke, for er der nogen anden forbindelse end navnet Tyskland mellem Kaliningrad og "tyskerne" i Sovjet? De fleste er efterkommere af bønder, der for mere end tohundrede år siden, inden der var noget der hed Tyskland, blev inviteret af Katarina den Store til at bosætte sig langs med Volga, og de kom for det meste fra helt andre områder i det tyske kulturrum. Idag taler mange af dem ikke tysk, men på grund af den tyske forfatning, der siger, at Forbundsrepublikken er hjemland for alle tyskere, har de ret til at komme til et Tyskland, der i forvejen har nok problemer med at integrere østtyskere og tyskere fra Rumænien og Balkan. Derfor ville det være nemmere, om man kunne bosætte dem nær Tyskland og alligevel i Rusland, men hvad så med de russere der allerede bor der, og hvad med Polen, der kan ane de geografiske konturer af mellemkrigstidens Europa, hvor Polen skilte Tyskland fra Tyskland, og hvad med litauerne der tog Memelområdet fra Østpreussen i 1923?

Selvom den officielle holdning både fra tysk og russisk side altså er, at Kaliningrad skal forblive en lidt speciel del af den russiske føderation, er befolkningen i Kaliningrad vant til, at politikker hurtigt kan ændre sig. Så selvom ingen siger det officielt mener mange, fra taxachaufføren over professoren til demografen, at tyskerne skridt for skridt kommer sivende ind i byen igen. Ikke med magt, men med pengenes stille indflydelse. For i et land, hvor man er vant til, at officielle beretninger er løgnagtige og opportunistiske, må man bruge sine egen forestillinger om de andre til at navigere rundt i det rum, der er tidens og historiens. Og her siger stereotypien om tyskeren, at han er punktlig, renlig, arbejdsom, præcis og med en hukommelse, der aldrig glemmer et tab, mens russeren er storhjertet, tilgivende, uorganiseret og lidt doven. I den logik må man enten holde tyskerne ude med magt eller finde en måde at eksistere på, side om side. I det spil ligger Kaliningrad placeret helt centralt mellem de to poler, der ser ud til igen at blive de dominerende i Europa: Berlin og Moskva.

Efter afskedsmiddagen den sidste aften hos professoren ser vi rystede smalfilm fra et liv i Kaliningrad. Strandliv i klitterne, picnic på voldanlægget og bryllupspar der lægger blomster på den 
ukendte soldats grav. Professoren viser mig sin nyeste bog om undervandslandskaber, som han skriver videre på, selvom der ikke længere er penge til at få den udgivet og intet videnskabeligt miljø til at modtage den. „Det er altid interessant at se andres kort, især over havbunden, for der er så meget der er usynligt, og så få punkter man ved noget om, at man må være en videnskabelig kunster, der tegner udfra sin fantasi, sin intuition og sin viden om hvordan det plejer at være. Derfor bliver ethvert kort forskelligt og siger ikke kun noget om det derude, men også om den, der har tegnet det". Og der mødes englen og professoren. For på samme måde som kortet hjælper med at navigere rundt $i$ landskabet hjælper fortællinger om historien til at navigere rundt $i$ tiden. Og bag det hele lurer filosoffen fra en anden tid, da denne ravnekrog også var en central udkant i Europa: "Alt som hører under det indre forestilles i tidsrelationer. Tiden kan ikke anskues som noget ydre, så lidt som rummet kan anskues som noget indre".

\section{Efterskrift}

I efteråret 1996 kunne man i baltiske aviser støde på en notits om, at Kaliningrad endnu engang skulle omdøbes, nu til „Korolev”. Det blev af visse intellektuelle set som en elegant linje tilbage til det historiske navn, da korol er russisk for konge. Den russiske ambassade i København kunne dog hverken be-eller afkræfte rygtet. Ifølge National News Service i Moskva er oplysningen i princippet rigtig, men fortolkningen forkert. Der var tidligere to Kaliningrad i Rusland, og den anden, en industriel forstad til Moskva, er netop blevet opkaldt efter den store russiske raketforsker Sergej Korolev. 